\title{
Perceptions of Prospective ICT Teachers Regarding Usability of Subliminal Message Techniques in Education
}

\author{
Prof. Dr. Hasan Arslan \\ Head of Department of Educational Sciences \\ Assistant Prof. Dr. Muzaffer Ozdemir \\ Department of Computer Education and Instructional Technology \\ Meltem Kuscu \\ MA of Education Management and Supervision \\ Canakkale Onsekiz Mart University/Turkey \\ doi: 10.19044/esj.2017.v13n7p81 URL:http://dx.doi.org/10.19044/esj.2017.v13n7p81
}

\begin{abstract}
Human brain is two hemispheres filled with secrets. What happens in the brain has always a research source and mystery for human. Some researchers associating human behaviors with the subconscious reported that if they reached to subconscious they could make the human demonstrate the desired behaviors. Researchers thinking like that have become the essential advisors for the advertisement sector trying to direct people to consumption especially. While the advertisement sector tries to make people buy things that don't need it also brought new concepts in the science world. The most known and emphasized one are subliminal messages.

The purpose of this study is to examine use of subliminal messages for education from the point of view of students Computer and Instructional Technologies Education (CEIT). Since subliminal messages are dealt in terms of information technologies generally, opinions of CEIT senior class students dominating this field were referred. Interview technique one of the qualitative research methods was used in the study. In this study 42 students participated in the research. According to findings of the study, CEIT students expressed an opinion that subliminal messages could be beneficial for the education. It was found out that the most preferred method for education materials to be prepared is cartoon for students. It was expressed that 25. square technique was the most proper method as the subliminal method.
\end{abstract}

Keywords: Subliminal message, $25^{\text {th }}$ square technique, Subthreshold, Educational Technology 


\section{Introduction}

Humankind walking on the way opened by technology have possibly misused what is good on this way as well. Subliminal messages appear before us to be the best example of this. Subliminal messages having a bad reputation among people are considered bad enemies embedded in movies, cartoon movies and advertisements to have a negative effect on the children's brains. Furthermore, subliminal messages encouraging harmful habits, hiding such feelings as death and fear in themselves or containing sexuality have become a situation which particularly disturb parents. For instance, as Guler (2008), Cetin (2013), Solmaz (2014) and Erdem (2015) state in their studies, skull modeling, illuminati or sexually explicit messages contained in the posters or contents of some Disney cartoon movies disturb those parents who have information on the subject. Great part of the studies carried out on subliminal messages is related to the advertising sector and the remaining small part to movies, cartoon movies and comics. Use of subliminal messages for educational purposes is only limited to some private enterprises providing personal development training and English education for the time being. These enterprises state that they use audio subliminal messages which promise teaching language by such methods as Neuro Linguistic Programming (NLP) in sleep, sleep-learning or embedding information in subconscious. When one studies the operating principles of these enterprises, it may be observed that they only prefer the sleep-learning methods through audio subliminal messages but they do not carry out any studies related to the other subliminal methods.

The problem sentence of this study is the examination of whether or not subliminal messages may be used for educational purposes. In this study, opinion of the CEIT students and instructors has been asked. The basic reason for choosing the CEIT department is that this department is a branch shaped within the technology-education-design triangle. And the reason for choosing the senior students of CEIT is that they have taken the basic subjects and that they are of an age group that is ready to start to work and appear before students. Besides, the fact that they have preliminary information about subliminal messages appears before us as an extra factor as they are related to their branch. It has been further thought that the students who took the subjects entitled "Material Design and Use in Education", "Multimedia Design" and Graphics and Animation in Education" given compulsorily in the CEIT department could have knowledge on the preparation of an animation or cartoon movie containing subliminal messages. 


\section{What Is a Subliminal Message?}

The influencing attempt made below the perception limit through our sense organs is called "sublimen". In Latin, "sub" means below and "limen" means threshold. Therefore, the term "subliminal" is defined as below the threshold (Izgoren, 2014). The term "subliminal" is defined as "that which remains below the conscious threshold". Subliminal messages correspond to the inputs which we cannot consciously notice with our sense organs (Cetin, 2013). A subliminal message represents a sign or message embedded in an object.

The first use of the term "subliminal" goes back to 1824. German philosopher and psychologist J. Friedrich Herbart used the term "subliminal" in order to define the perception below the conscious threshold (Erdem, 2015). Its initial use corresponds to the second half of the $19^{\text {th }}$ century. German physicist Volkman applied the initial subliminal techniques with the device called tachistoscope which he invented in 1859.

The very first person remembered when subliminal message is involved is James Vicary. The experiment he did in 1957 marked a new era in terms of subliminal message. In an experiment performed in the Fort Lee cinema house at New Jersey, the effect of subliminal messages on people was experimentally studied for the first time. In the movie entitled "The Picnic", such messages as "Are you hungry? Eat popcorn." and "Drink Coca Cola." were given in some frames by means of tachistoscope. After the study carried out on 45699 people, it was concluded that there was an increase of 57,5\% in popcorn sales and an increase of 18,1\% in Coca Cola sales (Guler, 2008; Eldem, 2009; Yolcu, 2010; Tokabas and Veli, 2012; Kucukbezirci, 2013; Serttas and Darıc1, 2014; Öztürk, 2014; Solmaz, 2014; Erdem, 2015).

Subliminal perception is the recording of a stimulus by proper sense organs before it reaches a conscious awareness (Smith and McCulloch, 2012). Even if the question "Are our decisions affected by subliminal messages?" has recently affected scientists and the people, the experimental data that have just appeared in recent times have started to reveal that it may be possible (Milyavsky, Hassin and Schul 2012). However, to make a persuasive experimental performance of subliminal processing constitutes a challenging task (Kouider and Dehaene, 2007). It is claimed in the results of various studies (Guler, 2008; Cetin, 2013; Solmaz, 2014; Erdem, 2015) that people have been manipulated by exposing to subconscious messages. In his study, Silva (2013) states that age or gender is not important and that people are exposed to subconscious techniques by the advertising sector so that they consume products notwithstanding they need them or not. 


\section{Subliminal Message Techniques}

Messages affecting the people's subconscious are prepared for sense organs. Messages are particularly formed on vision, sound and odor (Solmaz, 2014). Of these messages, those which are visual and audio may appear before us in advertisements, serials, cartoon movies, video clips, songs, posters and computer games (Guler, 2008). They may be used for various purposes from marketing the advertized product to making behavioral change in people. Subliminal message techniques are described below at visual and audio aspects.

The most frequently encountered and best known subliminal message technique is the $25^{\text {th }}$ frame technique (Solmaz, 2014; Erdem, 2015). While forming film frames, 24 frames are shown per second. In this way, human eye watches a flowing image instead of intermittent frames. Control intervals (i.e. $25^{\text {th }}$ frame) are left blank in order to ensure the arrangement of the film frames. In this subliminal method, it is possible to embed any desired image in this blank $25^{\text {th }}$ frame. Thus, while conscious cannot catch this image, subconscious can (Cetin, 2012; Erdem, 2015). These images may only be clearly seen in slow motion watching.

Another of the visual messages is the use of subconscious symbols. The best known of such symbols are "pentagram”, "number 666”, "all-seeing eye” and "checkered background”. They are symbols usually identified with an ideology or belief such as Judaism, Satanism, etc. (Solmaz, 2014).

Another visual message is masking the background (Biskin, 2014). Thanks to this technique, a desired image is reflected in the background while an event attracting the attention of the spectators is occurring in the foreground. For instance, it appears before us as a detail to which attention is not directly attracted but which will be noticed by subconscious just like a desired picture taking place in the background while a car is passing in the foreground (Erdem, 2015).

Another method which is at least as effective as visual subliminal messages is audio subliminal message techniques (Biskin, 2014). It is seen that audio subliminal messages are of three types by the methods of the formation (Solmaz, 2014). The first one is backward masking and the second one is backmasking. The third one is the subliminal personal development cassettes which are of a nature which may form an area of use rather than a method. In the backward masking technique, messages may be formed by hiding a low pitched sound behind a high sound. For instance, it is stated that a voice saying "Good teenagers, take off your clothes" is heard in a scene of the cartoon movie Aladdin produced by Disney (Erdem, 2015). Backmasking appears before us as a reverse recording of a message (Cetin, 2012). That is to say, it represents the messages revealed when a sound recording is listened reversely. For instance, it is stated that the Beatles' song 
"Rain" is the very first song in which backmasking is used (Biskin, 2014). The third methods which Solmaz (2014) mentions, i.e. subliminal personal development cassettes, was prepared for such purposes as stopping smoking, strengthening memory, teaching a foreign language, etc. and became a new market in the early 1990s.

\section{Place of Subliminal Messages in Education}

Subliminal messages especially show up in NLP and language education in the present day. It is stated that audio subliminal messages are used in these two fields by the sleep learning method. (e.g., www.gencgelisim.com; www.ingilizcedilkurslari.com.tr). The REM (Rapid Eye Movement) phase which is one of the two main phases of sleep is described as one which is open to learning. Therefore, sleep learning is carried out for this phase. Perceptional impositions carried out in the REM phase display an effect supporting learning as subconscious is awake (Ertem, 2015). Some private companies (e.g., www.gencgelisim.com; www.ingilizcedilkurslari.com.tr; www.uykudaingilizceogrenme.com) have stated that they provide education by the sleep learning method.

The fact that subliminal messages are only used in education in the form of audio messages by the sleep learning method makes one think that the use of subliminal messages in education is unjustly treated. Subliminal message techniques which could not reach the place they well deserved as they were considered to be a terrifying subconscious trap which was thought must be kept away from children and education due to their bad reputation should be able to show up in other fields of education as well. Therefore, studies should be carried out for the use of subliminal messages in education. For instance, studies for providing cognitive information or behaviors may be carried out on students through an experimental study. Educational videos may be edited for those students who have difficulties in learning. Bu this present study, it is intended to attract the attention to the affirmative aspects of subliminal messages and to create awareness on providing the education sector with a significant material.

In this context, the research questions are as follows:

1- $\quad$ May subliminal messages be used for educational purposes in the opinion of CEIT students and instructors?

2- $\quad$ In what fields would subliminal messages be more successful if they are used for educational purposes?

3- If the students and instructors themselves would prepare a work with subliminal content, what technique would they apply in what branch and to what age group? 


\section{Method}

\section{Participants}

Participants in the study are consisted of the fourth grade students of the CEIT Department of Canakkale Onsekiz Mart University (N=42, 20 female, 22 male, age range: 21-28). Considering the demographic properties, it is seen that participants are nearly in equal numbers by gender. In terms of age range, in consideration of students, it is seen that a young group is worked with in the ager range between 21 and 28 years. Participants are designated as $\mathrm{P}$ (Number) in the study.

\section{Research Model}

In the study, interview technique is used, which is one of qualitative research methods. Interview is more effective in benefiting from the experiences and views of individuals. As the people participating in the interview speak of their views in verbal way, they have a change to express themselves in an easier manner (Yıldırım and Şimşek, 2011).

In this context, interview technique has been used in order to be able to learn the ideas and thoughts of the CEIT students on the matter in depth. Further, information has also been obtained in terms of revealing the similarities and differences between the students' viewpoint on the matter. It is assumed that the participants have given sincere replies during the interview.

Semi-structured interview questions have been prepared in the study in order to seek answers to the research questions. Interview questions have been prepared in accordance with the research carried out on the matter by researchers and presented to two specialists from the education department and CEIT department for their opinion. A pilot study has been carried out upon specialists' opinion and the research questions have been given their final form.

\section{Findings}

In order to evaluate usability of subliminal messages for educational purposes, senior students of the CEIT Department of the faculty of Education of the Canakkale Onsekiz Mart University have been asked questions on the matter. Replies given to each question have been evaluated within themselves. Each view stated including the most repeated statements have been included into the replies given.

Replies of the students have been first individually evaluated. Then, similar and different thoughts have been studied and a conclusion reached. Analyses made and findings obtained are as follows for each question. 


\section{Question 1: What is a subliminal message in your opinion?}

Of the participants, 18 have used the term "Subconscious", 18 the term "Unaware" and 14 the term "Hidden". The point referred to by all participants has appeared before us as embedding a message hidden in different objects, images, sounds or videos in the subconscious through indirect ways without allowing individuals to be aware of it. Two of the participants have described a subliminal message as various signs. Two participants have used the term "implicit learning".

P2 has spoken on the matter as follows: "A subliminal message is a hidden content. It is a hidden association hidden in the principal image, which is wanted to be given but given without allowing the viewer to be aware of it." P9 has spoken about the subliminal messages as follows: "Embedding a behavior, form and a material which will get reaction when given directly in one's mind within a plotline not to come to one's attention."

Consequently, the common themes appear before us as subconscious and hidden message. It is seen that all participants know of the subliminal message concept and explain it with different comments. The outstanding definition has been that messages are conveyed to the subconscious without being noticed and by hiding them in objects. This shows that the students have a good command of the matter due to both their branches and their age group. Replies they have given to the questions conclude that the level of preparedness of the students for the subject of subliminal messages is sufficient.

\section{Question 2: What are the subliminal message techniques?}

When the replies from the participants are examined, it is seen that the most known techniques are the $25^{\text {th }}$ Frame technique and product placement. Nine of the participants have given as a reply the $25^{\text {th }}$ Frame technique and nine the advertising technique known as product placement. Even if not technically, nine participants have replied as audio and visual subliminal. Seven of the participants have replied as "cartoon movie", three as "caricature" and two "movies and serials". One participant from each group has stated their opinion as clips, font style and various symbols. Another participant has represented them as all techniques which will attract the attention of the brain and made a generalization. Four participants have stated that they do not have any information on the matter and seven participants have not replied the question.

P15 has said the following on the matter: "For instance, subliminal messages are given through hidden objects in the $25^{\text {th }}$ frame in cartoon movies." P33's reply is as follows: "They are usually given in different images by age groups and for different situations. Messages containing 
religion, money, sexuality are given to younger age groups through cartoons and to adult age groups through serials and cinema movies."

As a result, according to the replies given, young people know the $25^{\text {th }}$ Frame technique and product placement or object placement technique used in advertising best. They describe the other techniques as visual and audio ones and state that subliminal messages are usually used in such images as cartoons, movies, serials caricatures, etc. reflections of the fact that studies have been carried out especially in advertising in literature appears before us here as well. Because the product placement method frequently encountered in the replies given is a practice related to the advertising sector.

\section{Question 3: To what extent do you think subliminal messages affect the subconscious?}

Of the participants, 20 have stated that as individuals are subjected to subliminal messages unaware, the subconscious is affected to a great extent. Eight of the participants have stated that they affect the behaviors and lives of individuals. Five participants have stated that children are particularly affected, and four participants have given a completely opposite reply, saying that it will vary by age group and that they do not have any effect on little children. Three participants have emphasized that the effect will be seen in the long run and three participants have stated that subliminal messages will expand the world of imagination and urge the people to search and learn. Two participants have stated that they depend on an individual's perception. Of four participants who have stated that subliminal messages are not effective, three are female students and one is a male student.

We have encountered replies containing different views. P17's reply is as follows: "Most people fail to notice that there is a subliminal message in the situation they are in. However, the subconscious perceives such messages and most people are much affected even if they fail to notice the message for the scene they watch and see. People improve their world of imagination unawares by imagining more." P19 who has stated a different view has replied as follows: "Subliminal messages are entirely related to the subconscious and perspective. They are related to what a person sees in the given message and to what it reminds him. A desire for seeking a subliminal message in the messages given occurs in the subconscious." According to P24 who argues that a subliminal message does not have any effect: "These may vary by their degree. My opinion is that an individual fails to notice small subliminal messages in cartoons and I do not think they have any effect."

As a conclusion, the opinion that subliminal messages usually affect the subconscious to a great extent even if they vary by age groups prevails. 
Participants usually think that subliminal messages have such power which may cause behavioral changes and affect large masses in the long run. The fact that three out of four students who think that subliminal messages do not have any effects are female students shows that there is a difference of opinion between genders.

\section{Question 4: In what branches do you think subliminal messages may be more successful?}

Replies from the participants appear before us in a wide range. The most repeated replies are informatics uttered by five participants, all technology-supported branches and visual branches uttered by four participants each. These are followed by preschool branches uttered by three participants. Turkish is uttered by two participants, education by two, graphics by two, difficult courses by one, philosophy by one, astronomy by one and positive sciences by one participant. Of those participants who see the branch concept from a different perspective, 15 have replied as advertisements, nine as movies, eight as cartoons, five as serials, four as radio and television and one as politics, thus adding a different perspective and comment to the matter. Two of the participants have not replied the question while one participant has replied, "I do not know."

P4's comment on the matter is as follows: "Possibility of being successful in technology-supported branches is higher. Transmission of subliminal messages has become easier with developing technology." Using a generalized expression, P14 has replied, "They may be in preschool teaching as they may be in all branches." According to P21 who has emphasized an important point, "They will be effective in permanency of important features in difficult subjects." Giving a reply related to his P30 has said, "They may show their effects in all branches where education and training are provided in technical branches just like ours, considering the issue of age, of course."

As a result, it appears before us as an option that the participants who have stated that they may be more successful in those branches associated with technology may have replied under the influence of their own branches. Apart from this, thanks to those participants who have enriched the question with their different comments, we have been ensured to have some idea about the most effective methods. Particularly, the idea of using subliminal messages in the teaching of difficult subjects and subjects which are difficult to understand has been a reply which thoroughly reflects the content and objective of this study. 
Question 5: If you are to prepare a study for students, to what age group would you prepare a subliminal message and in what branch and by the use of what techniques?

According to the replies from the participants, 10 participants have stated that they want to prepare a content for preschool, 16 participants for elementary school, three participants for both preschool and elementary school, two participants for secondary school, seven participants for high school and three participants for university level. Two participants have replied that they could be applied to each and every ager group and two participants have replied that they would not use subliminal messages. Of branches, Turkish, education, history and informatics have been each told by two participants. Web designing, elementary school programs, positive sciences, technology, social media subjects and success and Canakkale Wars have been each stated by one participant as the subjects and lessons which will be taught to students by preparing subliminal messages. It has been the cartoon movie technique which has been stated most as a subliminal practice technique by 10 participants. Seven participants have replied visual, three participants animation, two participants sound, two participants $25^{\text {th }}$ frame, two participants computer games and two participants caricature. One participant has replied as movie, one as video and one as clip. One participant has not replied the question.

P26's reply on the matter has been as follows: "I would do it by preparing caricatures and presenting them to the students of the 10-11 age group. I could apply it in my own branch.” P35 who has given an opinion to the contrary on the matter has represented his views as follows: "Instead of giving subliminal messages, I would think how I could make the subject I want to convey and to be permanent more interesting."

As a result, considering it from the standpoint of students, it is observed that while the replies from female students display an equal distribution among age groups, the male students usually identify the students at elementary school level as the target group. It has been revealed that while male students prefer mathematical subjects, female participants have preferred verbal subjects. The common view of all the participants is usually the use of subliminal messages in the form of cartoons and visual content. It is seen that two participants who have said that they do not want to use subliminal messages are male students.

\section{Question 6: What would you like to say about the negative image of subliminal messages?}

To express the replies from the participants at a common denominator, the opinion as to the fact that subliminal messages have a bad reputation as they are usually employed to give negative contents prevails. 
Two participants who have stated that they have not seen any positive examples in the matter have stated their opinion by saying that any positive examples are not known even if there are any. Two participants have stated that even if the message is positive, it is not ethical to transmit some things to the subconscious of a person without allowing him to be aware of it. Two participants who have stated their opinion half-jokingly have said that they think that subliminal messages are a game of the United States or secret powers. Of the participants, eight students have not replied the question.

P25 who has approached the matter with severe criticism has spoken as follows: "Subliminal message is an adversity all in itself. One of the methods which we do not want and are not accustomed and which is used by those countries that want to affect us malevolently." Opinion of P28 who has approached the matter in a more constructive way is as follows: "When $a$ subliminal message is mentioned, a negative impression directly comes to mind. I think this has to change. And to do this, positive efforts must increase."

As a result, it is seen that all of the participants agree to the fact that negative use of subliminal messages is disturbing. The fact that positive examples must be multiplied so that subliminal messages may now relieve of their negative image appears before us as a demand from the participants. The replies coming in direct proportion with the objective of this study show that subliminal messages must be relieved of their bad reputation and it must be aroused as an idea in minds that they may be used for educational purposes as well.

When all replies are examined in general, it is found out that a majority of the CEIT students consider the matter in a positive way. It is understood that the thought that subliminal messages will bring about positive results if they are used in education. Accordingly, it is stated that they may be given particularly to younger age groups through cartoon movies both in mathematical and non-mathematical courses and in intangible concepts. However, attention is also drawn to so sensitive an issue. Even if the messages have positive contents, ethical compliance of conveying a message to a person's subconscious without making him aware of it creates question marks in minds. According to the picture so revealed, considering the matter from the viewpoint of CEIT students, subliminal messages appear before us as a practice which should be tried in educational environment.

\section{Conclusion and Suggestions}

The adventure of affecting the subconscious that started upon the invention of the device called tachistoscope in the middle of the 1800s is now used as an instrument to manipulate people in the form of subliminal messages in a wide range from advertising to politics. To make behavioral 
changes in people through the messages which the conscious cannot perceive but the subconscious directly receives without straining them -and to usually do this in order to market a product or serve some ideologies has caused the subliminal messages to take shape as a negative concept in the minds of people. Subconscious messages are not bad ones, but what makes them bad is the objectives. It is concluded that regardless of how positive they are, even if the fact that the effects created by subconscious messages occur out of the knowledge of people confuses the people, it is required to see their effect in education.

By this study, perceptions of prospective ICT teachers regarding subliminal message techniques for educational purposes is studied. In accordance with the answers of students participating the study, they were seen to have a prior knowledge about subject. It is observed that the majority of the participants positively see the education which can be done through subliminal messages. Usability of subliminal messages in education appears before us as a material work which at least deserves a try. It is concluded that subliminal messages may be prepared in mathematical, non-mathematical, artistic and intangible areas. The result of being able to be used for secondary and high school students was shown up according to participant instructors. However, according to participant students who are in the view that especially younger students may be effected with this situation, it resulted in they can be given education with the messages which can be used in cartoon movies. It is further concluded that as there may be any course material, videos and course materials with subliminal contents may be prepared in such issues as supporting the children with learning difficulties, teaching them intangible concepts and giving them various vital skills. As a matter of fact, being emphasized as a likely means of supporting the imagination for younger student groups, subliminal messages were stated as positive. It is expressed that the effects of subliminal messages may cause the change in behavior in long term. Therefore, it has been concluded that they can not only be used for learning for younger children but to change the behavior. In terms of method, it has been understood that the $25^{\text {th }}$ square is the most effective technique of the using of the subliminal messages.

As a great majority of the studies carried out in connection with subliminal messages are carried out via advertising sector, number of the studies in other areas should be increased. Thus, society should be made conscious that subliminal messages may be used in areas other than advertising. For instance, they may be included into the applications and works carried out in the area of education even if they are few and limited. Not only experimental applications may be made in the subsequent studies, but, apart from CEIT, studies may be carried out, for instance, with visual arts departments for poster works and with music departments for audio 
subliminal messages. The subject can be enhanced with different studies in different branches, thus, the real effect of subliminal messages can be revealed under the surveys.

\section{References:}

1. Biskin, F. (2014). Subliminal A. Ş. Tüket, Itaat Et. Ankara: Elma Yayınevi.

2. Cetin, M. (2013). The Role of Subliminal Messages at Cultural Industry Through Mediatocracy, Unpublished Master's Thesis, Pamukkale University, Social Science Institute, Sociology Department, Denizli.

3. Cetin, Y. (2012). Subliminal Mesajlar: Zihin Simsarlar1, Fatih Üniversitesi, Genç Kariyer Penceresi. http://www.kariyerpenceresi.com/?yazarlarimiz,23,148/subliminalmesajlar-zihin-simsarlari.html. Access Date: 7.10.2015.

4. Erdem, Ö. (2015). Hidden Advertising And Subliminal Messages on Television And Cinema, Unpublished Master's Thesis, Marmara University, Social Science Institute, Radio Television And Cinema Department, İstanbul.

5. Ertem, S. (2015). Uyurken Bile Öğrenmek İster misiniz? http://www.gencgelisim.com/ v2/kategoriler/57-ogrenme/1728uyurken-bile-ogrenmek-ister-misiniz.html. Access Date: 07.10.2015.

6. Guler, H. (2008). Beyond Perception: Subliminal Advertising Impact of Subliminal Advertising on Consumer Behavior, Unpublished Master's Thesis, Kocaeli University, Social Science Institute, Public Relations And Publicity Department, Kocaeli.

7. Izgoren, A. Ş. (2014). Eşikaltı Büyücüleri. Ankara: Elma Yayınevi.

8. Kouider, S., \& Dehaene, S. (2007). Levels of processing during nonconscious perception: a critical review of visual masking. Philosophical Transactions of the Royal Society of London B: Biological Sciences, 362(1481), 857-875.

9. Kucukbezirci, Y. (2013). Techniques of Subliminal Message Sending And The Effects of Subliminal Messages on Society, Turkish Studies - International Periodical For The Languages, Literature and History of Turkish or Turkic, 8 (9), s. 1879-1894, Ankara, Türkiye.

10. Milyavsky, M., Hassin, R. R., \& Schul, Y. (2012). Guess what? Implicit motivation boosts the influence of subliminal information on choice. Consciousness and cognition, 21(3), 1232-1241.

11. Serttas, A. ve Darıcı, S. (2014). Subliminal mesajların reklamlarda kullanımı: Türkiye örneği.

12. Silva, K. S. (2013). Resumen Del Libro: Seduccion Subliminal, Wilson Brian Key. Psicología Del Consumidor (Tüketici Psikolojisi). 
Görsel Sanatlar Fakültesi, 29 Mayıs 2013, Coahulia Üniversitesi, İspanya.

13. Smith, P.K., McCulloch, K.C., (2012). Subliminal Perception, Encyclopedia of Human Behavior (2th Edition), 551-557.

14. Solmaz, I. (2014). Subliminal Advertising Activities in Neuromarketing And Its Effects on Consumer Perception, Unpublished Master's Thesis, Gediz University, Social Science Institute, Business Administration Department, İzmir.

15. Tokabas, E. ve Veli, T. Y. (2012). Reklam ve İdeoloji: Subliminal Reklam ve Örnek İncelemeler. Galatasaray Üniversitesi, İstanbul.

16. Yıldırım, A. ve Şimşek H. (2011). Sosyal Bilimlerde Nitel Araştırma Yöntemleri. Ankara: Seçkin Yayıncılık.

17. Yolcu, T. (2010). As A Marketing Communication Tool For Product Placement - A Study on The Series And Films, Unpublished Master's Thesis, Sakarya University, Social Science Institute, Business Administration Department, Sakarya. 